\title{
SIKLUS PERKEMBANGAN PEMBUNGAAN DAN PEMBUAHAN SERTA PEMBENTUKAN BUAH KEMENYAN (Styrax benzoin) DI AEK NAULI
}

\author{
Flowering and Fruiting Development Cycle and Fruit Set \\ of Kemenyan (Styrax benzoin) at Aek Nauli \\ Dida Syamsuwida ${ }^{1)}$, Aam Aminah", Nurkim Nurochman ${ }^{1)}$, \\ E. Baeni Sumarni ${ }^{1)}$, dan/and Johan Ginting ${ }^{2}$ \\ ${ }^{1)}$ Balai Penelitian Teknologi Perbenihan Tanaman Hutan, \\ Jl. Pakuan, Ciheuleut, PO Box 105, Bogor \\ Telp./Faks. 0251-8327768 email:dida_syam@yahoo.co.id \\ ${ }^{2)}$ Balai Penelitian Kehutanan, Aek Nauli \\ Kampus Kehutanan Aek Nauli \\ Jl. Raya Parapat Km 10,5 Ds. Sibaganding, Parapat - Sumatra Utara \\ Telp. 0625-41659, Faks. 0625-891963
}

Naskah masuk : 9 Juli 2013; Naskah diterima : 21 April 2014

\begin{abstract}
Determining the development of flowering and fruiting, as well as measuring the number offlowers developed into fruits is important to predict the time of harvesting and to estimate the production of seeds. The study aims to find out the reproductive cycle and fruits set of kemenyan (Styrax benzoin). There were ten selected trees flowering on the branches at the Western and Eastern parts. The number of flowers and fruits per inflouresence were counted to measure the fruit set of kemenyan. The revealed that reproductive cycle of kemenyan at Aek Nauli in the period of 2012-2013 was proceeded for eight to nine months initiated from reproductive buds in June-July, flowers burst in August and matured fruits in February-March. Fruit set of kemenyan was around 10-13\%. There were no different flowering-fruiting behaviour between West and East.
\end{abstract}

Keywords: Flowering phenology, reproductive cycle, seed production, Styrax benzoin

\begin{abstract}
ABSTRAK
Jaminan ketersediaan benih secara terus menerus memerlukan informasi tentang fenologi pembungaan dan pembuahan. Informasi ini sangat bermanfaat untuk menduga waktu pemanenan yang tepat dan memperkirakan potensi produksi benih. Jumlah maksimum produksi benih yang dihasilkan dapat dideterminasi dari ratio bunga menjadi buah. Tujuan penelitian adalah mengetahui siklus reproduksi dan pembentukan buah jenis kemenyan (Styrax benzoin) di Aek Nauli. Pohon sampling dipilih sebanyak10 pohon dengan dua perlakuan yaitu pembungaan pada arah Timur dan Barat. Jumlah bunga dan buah per malai dihitung untuk mengukur ratio bunga menjadi buah (fruit set) tanaman kemenyan. Hasil pengamatan menunjukkan bahwa siklus reproduksi tanaman kemenyan di arboretum Aek Nauli pada periode tahun 2012-2013 berlangsung selama 8-9 bulan diawali dari terbentuknya tunas generatif pada bulan Juni-Juli, bunga mekar Agustus dan buah masak pada bulan Februari-Maret. Ratio buah/bunga (fruit set) kemenyan berkisar antara 10-13\%. Pembungaan pada dahan bagian Barat dan Timur tidak menunjukkan perbedaan nyata.
\end{abstract}

Kata kunci: Fenologi, produksi benih, siklus reproduksi, Styrax benzoin

\section{PENDAHULUAN}

Fenomena alam yang terjadi pada siklus hidup tanaman seperti gugurnya daun, pembungaan dan pembuahan biasanya bervariasi menurut kondisi lingkungannya, terutama jika spesies tersebut dapat hidup di kisaran tipe iklim dan edafik yang luas (Cleland et al., 2012). Keberhasilan proses reproduksi suatu tanaman bergantung pada kemampuannya melampaui tahapan-tahapan perkembangan yang dimulai dengan inisiasi kuncup bunga dan berakhir dengan kematangan buah dan biji. Kegagalan pada salah satu tahapan perkembangan ini dapat berakibat pada turunnya produktivitas biji sebagai hasil akhirnya (Owens et al., 1991). Oleh karena itu informasi tentang 
pembungaan dan pembuahan, melalui studifenologi pembungaan, sangat diperlukan. Pemahaman tentang fenologi pembungaan dan pembuahan akan meningkatkan kualitas dan kualitas benih melalui prediksi waktu pemanenan dan produksi benih yang tepat setiap tahun.

Fenologi perbungaan suatu jenis tumbuhan adalah salah satu karakter penting dalam siklus hidup tumbuhan karena pada fase itu terjadi proses awal bagi suatu tumbuhan untuk berkembang biak. Suatu tumbuhan akan memiliki perilaku yang berbeda-beda pada pola pembungaan dan pembuahannya, akan tetapi pada umumnya diawali dengan pemunculan kuncup bunga dan diakhiri dengan pematangan buah (Tabla \& Vargas, 2004). Penelitian yang dilakukan oleh Loveless et al. (2006) mengamati fenologi perbungaan pada Swietenia macrophylla dan diakhiri pada evaluasi tingkat buah masak.

Proses pembungaan mengandung sejumlah tahap penting, yang semuanya harus berhasil dilalui untuk memperoleh hasil akhir yaitu biji, dan masing-masing tahap tersebut dipengaruhi oleh faktor-faktor internal dan eksternal yang berbeda. Setiap bunga memiliki potensi untuk berkembang menjadi buah dan benih, tetapi hasil pengamatan menunjukkan bahwa meskipun pembungaan merupakan prasyarat untuk pembuahan, namun pembungaan yang banyak terkadang menghasilkan produksi benih yang rendah. Pada kenyataannya hanya sebagian dari bunga yang berkembang menjadi buah dan benih yang baik walaupun pada musim benih yang baik. Hal ini terutama tampak jelas pada jenisjenis Angiosperma dengan bunga yang kecil dan buah yang besar (Schmidt, 2000).

Kemenyan (Styrax benzoin) adalah tanaman hutan yang menghasilkan produk bernilai tinggi penghasil getah yang dapat dimanfaatkan untuk pembuatan dupa dan kosmetik. Di arboretum Balai Penelitian Kehutanan Aek Nauli, Pematang Siantar, jenis ini tumbuh baik dan telah mengalami pembungaan dan pembuahan beberapa kali. Akan tetapi, informasi dan data mengenai fenologi pembungaan dan pembuahan masih sangat terbatas termasuk siklus perkembangan bunga hingga buah serta besaran ratio bunga menjadi buah. Informasi ini sangat bermanfaat untuk mendukung budidaya penanaman kemenyan dalam upaya pengadaan benih secara berkelanjutan. Tujuan penelitian adalah mengetahui siklus reproduksi dan pembentukan buah kemenyan di Arboretum Aek Nauli.

\section{METODOLOGI}

\section{A. Bahan}

Plot penelitian dibuat pada kawasan Arboretum Balai Penelitian Kehutanan (BPK) Pematang Siantar yang secara geografis terletak pada $2^{\circ} 41^{\prime}$ $-2^{\circ} 44^{\prime}$ LU dan $98^{\circ} 58^{\prime}$ BT dan secara administratif termasuk Desa Sibaganding, Kecamatan Girsang Sipanganbolon, Kabupaten Simalungun (Sumut). Lokasi plot merupakan daerah pegunungan pada ketinggian $1.100 \mathrm{~m}-1750 \mathrm{~m}$ dpl dengan kemiringan antara 3-65\% (www.fordamof.org/files/AnuAek\%20Nauli.pdf). Suhu rata-rata $21^{\circ} \mathrm{C}$, curah hujan $111-442 \mathrm{~mm} /$ bulan dan kelembaban antara 78-85\% (BMKG, 2013). Sebanyak 10 pohon kemenyan dengan umur yang sama dipilih untuk sampel pengamatan pembungaan dan pembuahan.

\section{B. Metode}

Sebanyak 10 pohon induk yang sedang bertunas dipilih untuk bahan sampel pengamatan yang diukur tinggi dan diameter pohonnya. Dari setiap pohon terpilih, ditandai 5 cabang produktif di bagian Barat dan 5 cabang produktif di bagian Timur sebagai ulangan. Pengamatan terhadap tahap-tahap perkembangan bunga (Owens et al., 1991) dilaksanakan terhadap cabang-cabang produktif yang telah dipilih dan berada pada posisi arah timur dan barat. Tahap-tahap yang diamati mulai dari saat terlihatnya tanda bakal bunga, terjadinya tunas bunga, bunga mekar (anthesis) hingga bunga layu. Selain itu perlu diamati pula perbedaan bunga betina dan jantan. Untuk memudahkan pengamatan dibuat tabel pengamatan bunga. Selain waktu juga dicatat perubahan ukuran, warna, bentuk bunga, jumlah bunga per tangkai/cabang produktif pada setiap posisi arah matahari. Pengamatan dilakukan setiap hari selama periode pembungaan.

Pengamatan perkembangan buah merupakan kelanjutan dari pengamatan perkembangan bunga. Tahap-tahap yang diamati mulai dari waktu terlihatnya tanda bakal buah, terbentuknya buah, buah muda dan buah masak. Selain waktu juga dicatat perubahan ukuran, warna dan bentuk buah serta jumlah buah/biji.

Jumlah bunga dan buah per malai dihitung untuk mengetahui nilai fruit set Kemenyan. Perkembangan buah dianalisis dengan mengukur dimensi buah masak pada dahan bagian Barat dan Timur. 


\section{Analisis Data}

Data pembentukan bunga dan buah dianalisis menggunakan uji $\mathrm{t}$ berpasangan (paired t-test). Uji komparasi dilakukan antar dua nilai berpasangan yaitu nilai di bagian barat dan di bagian timur pada setiap pohon sampel (Faruk, 2010).

\section{HASIL DAN PEMBAHASAN}

\section{A. Hasil}

\section{Siklus perkembangan bunga dan buah kemenyan}

Pohon Kemenyan yang diamati tinggi total rata-rata 11,2 meter, tinggi bebas cabang rata-rata 4,5 meter dan rata-rata keliling pohon $61,5 \mathrm{~cm}$. Kondisi di lapangan pada saat pengamatan sebagian ada juga yang sedang berbunga dan berbuah muda hanya tidak merata. Dari hasil pengamatan banyak bakal bunga terlihat muncul bersamaan dengan munculnya tunas vegetatif baru, tapi ada juga bakal bunga muncul 3-6 daun di bawah pucuk tunas baru dan banyak bunga gugur setelah mekar.
Dalam satu siklus reproduksi, mulai dari bakal bunga sampai buah muda dibutuhkan wak-tu antara 74-94 hari. Dari bakal bunga hingga bunga mekar diperlukan waktu antara 35-62 hari. Setelah bunga rontok (6-25 hari) yang diikuti dengan pembesaran ovarium maka terindikasi adanya penyerbukan. Pada kemenyan fase ini memerlukan waktu anta-ra 6-17 hari. Pembesaran ovarium akan terus berkembang membentuk buah kecil yang memerlukan waktu sekitar 5-16 hari (Tabel 1). Ilustrasi siklus perkembangan bunga menjadi buah kemenyan dapat dilihat pada Gambar 1.

Bakal bunga atau tunas generatif kemenyan mulai terlihat pada pertengahan bulan Juni hingga Juli, kemudian tangkai bakal bunga muncul dan memanjang terlihat pada akhir bulan Juli. Pada bulan Juli-Agustus kuncup bunga pada malai, berkembang dan terlihat petal (kelopak bunga) berwarna putih. Bunga mekar umumnya terjadi pada bulan Agustus, beberapa hari kemudian bunga rontok. Pada akhir bulan Agustus hingga awal September bunga yang rontok sebagian memperlihatkan pembesaran pada ovarium

Tabel (Table) 1. Waktu perkembangan pembungaan-pembuahan kemenyan (hari) (Periods of floweringfruiting development of kemenyan (days))

\begin{tabular}{|c|c|c|c|c|c|c|c|c|c|c|c|}
\hline \multirow{2}{*}{$\begin{array}{l}\text { Tahap perkembangan } \\
\text { (Development stages) }\end{array}$} & \multicolumn{10}{|c|}{ No. Pohon (Tree no) } & \multirow{2}{*}{$\begin{array}{c}\text { Rata- } \\
\text { rata } \\
\text { (Averages) }\end{array}$} \\
\hline & 1 & 2 & 3 & 4 & 5 & 6 & 7 & 8 & 9 & 10 & \\
\hline 1. Bakal bunga (Flower primordia) & 5 & 5 & 7 & 9 & 7 & 6 & 5 & 5 & 6 & 9 & 6 \\
\hline $\begin{array}{l}\text { 2. Bakal bunga berkembang } \\
\text { (Dev. of flower primordia) }\end{array}$ & 6 & 8 & 8 & 10 & 7 & 7 & 5 & 6 & 6 & 9 & 7 \\
\hline $\begin{array}{l}\text { 3. Tangkai bunga memanjang } \\
\text { (Flower stalk lenghten) }\end{array}$ & 21 & 20 & 16 & 10 & 12 & 8 & 8 & 9 & 6 & 16 & 13 \\
\hline $\begin{array}{l}\text { 4. Kuncup bunga muda } \\
\text { (Early flower bud) }\end{array}$ & 8 & 7 & 8 & 6 & 5 & 4 & 4 & 4 & 5 & 5 & 6 \\
\hline $\begin{array}{l}\text { 5. Kuncup bunga memutih } \\
\text { (Creamy flower bud) }\end{array}$ & 8 & 9 & 8 & 6 & 5 & 4 & 4 & 3 & 3 & 6 & 6 \\
\hline $\begin{array}{l}\text { 6. Kuncup bunga membesar } \\
\text { (Developed flower bud) }\end{array}$ & 7 & 7 & 4 & 7 & 6 & 8 & 7 & 9 & 10 & 8 & 7 \\
\hline 7. Bunga mekar (Flower burst) & 5 & 6 & 7 & 4 & 6 & 14 & 5 & 8 & 8 & 7 & 7 \\
\hline 8. Bunga rontok (Flower abortion) & 13 & 6 & 12 & 8 & 10 & 8 & 13 & 10 & 17 & 8 & 11 \\
\hline $\begin{array}{l}\text { 9. Pembesaran ovarium } \\
\text { (Developed ovary) }\end{array}$ & 6 & 12 & 6 & 18 & 16 & 11 & 17 & 25 & 7 & 16 & 13 \\
\hline $\begin{array}{l}\text { 10. Buah muda kecil } \\
\text { (Small young fruits) }\end{array}$ & 12 & 12 & 5 & 16 & 12 & 6 & 10 & 7 & 6 & 10 & 10 \\
\hline Jumlah total hari & 91 & 92 & 80 & 94 & 86 & 76 & 78 & 76 & 74 & 94 & \\
\hline
\end{tabular}



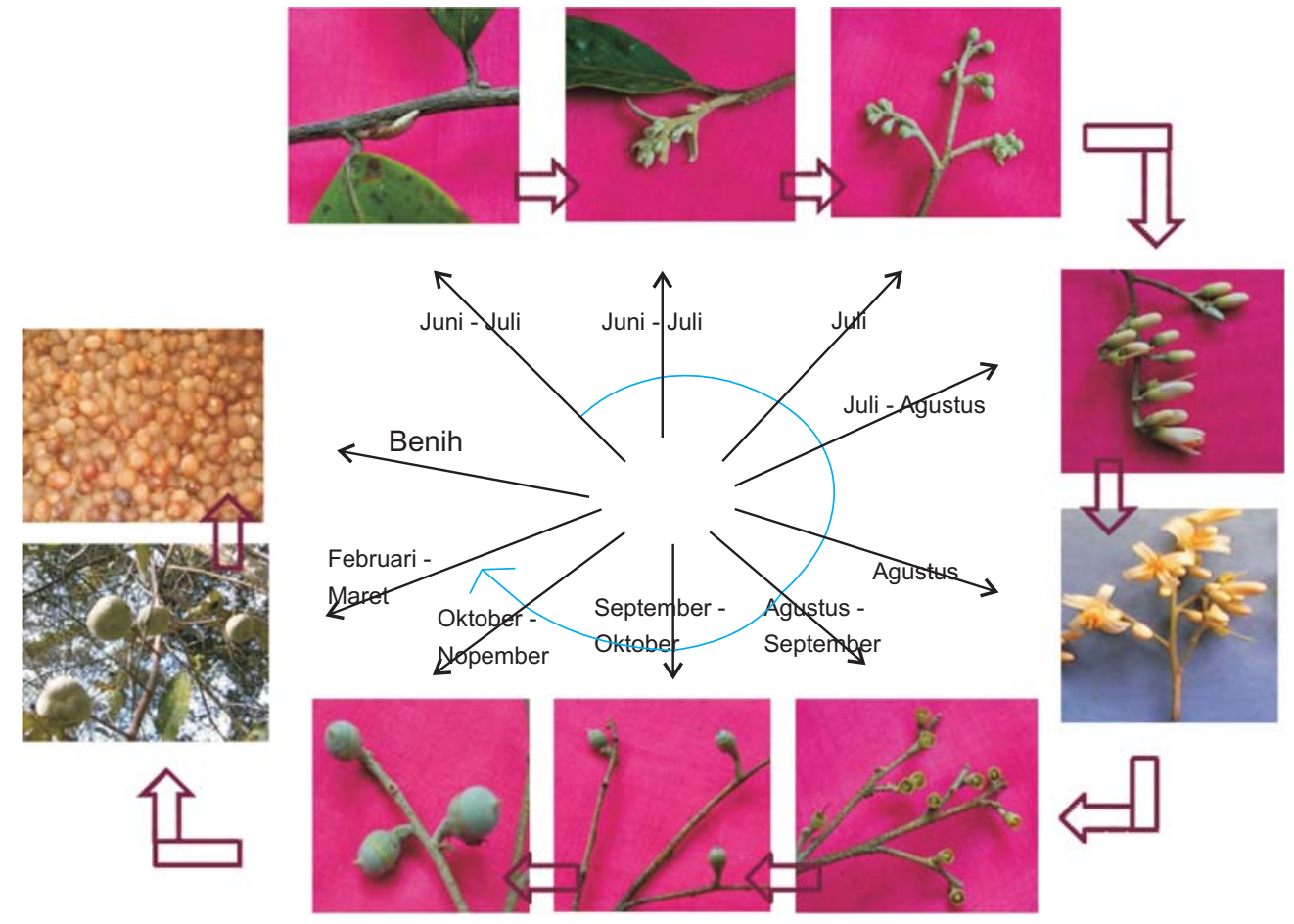

Gambar(Figure)1. Siklus reproduksi tanaman kemenyan di Arboretum Aek Nauli pada periode tahun 2012-2013. (Reproductive cycle of kemenyan at Aek Nauli Arboretum in a periods of 2012-2013)

yang mengindikasikan telah terjadi pembuahan (fertilisasi) dan berkembang menjadi buah muda kecil pada bulan September-Oktober. Pada bulan Oktober-Nopember ukuran buah membesar dan sebagian badan buah masih ditutupi sepal berwarna hijau keabuan. Buah masak siap panen terjadi pada bulan Februari-Maret yang ditandai dengan warna kulit buah hijau dan bentuk buah membulat dengan sedikit lekukan.

Dengan demikian, siklus perkembangan pembungaan hingga pembuahan jenis kemenyan berlangsung selama 74-94 hari atau sekitar 8-9 bulan, yang terjadi selama periode tahun 20122013 di Arboretum Aek Nauli. Pada umumnya buah kemenyan berisi satu biji. Biji atau benih yang masak berwarna cokelat yang dikeluarkan secara manual dengan mengerat kulit buah.

\section{Ratio pembentukan buah (fruit set) kemenyan \\ Ratio bunga menjadi buah (fruit set) tanaman} kemenyan yang tumbuh pada cabang ranting di bagian barat dan di bagian timur masing-masing berkisar antara 9-17\% dan 4-16\% yaitu dengan jumlah bunga kemenyan per malai di bagian barat berkisar antara 11-21 bunga dan bagian timur 12-22 bunga, sedangkan jumlah rata-rata buah muda di bagian barat antara 1-3 buah dan bagian timur 1-2 buah (Tabel 2).

Hasil pengujian statistik menyatakan bahwa tidak ada perbedaan nyata antara posisi pembungaan di arah Barat dan Timur sehubungan dengan variabel reproduksi seperti jumlah bunga, jumlah buah dan ratio buah/bunga (fruit set) (Tabel 3).

Pembungaan dan pembuahan tanaman kemenyan pada ranting bagian Barat maupun bagian Timur hampir sama banyaknya $(\mathrm{P}>0,05)$. Dilihat dari ukuran, pada ranting bagian barat dan timur, buah kemenyan juga memiliki ukuran yang relatif sama yaitu berkisar antara diameter 2,63-2,89 $\mathrm{cm}$, panjang $1,98-2,22 \mathrm{~cm}$ di bagian barat dan diameter $2,56-3,06 \mathrm{~cm}$ dan panjang 2,09-2,25 $\mathrm{cm}$ di bagian timur (Tabel 4).

Hasil pengujian statistik menyatakan bahwa tidak ada perbedaan nyata antara posisi pembungaan di arah Barat dan Timur sehubungan dengan dimensi buah yaitu ukuran panjang dan diameter buah (Tabel 5). Seperti halnya jumlah bunga dan buah kemenyan, secara statistik ukuran buah muda dewasa, baik panjang maupun diameter menunjukkan tidak berbeda nyata antara buah pada posisi dahan di bagian Barat dengan di bagian Timur. 
Tabel (Table) 2. Jumlah bunga dan buah per malai kemenyan serta fruit set pada cabang bagian Barat dan Timur (Number of flower and fruit per inflouresence, and fruit set of kemenyan in the West and East)

\begin{tabular}{ccccccc}
\hline \multirow{5}{*}{ No } & \multicolumn{5}{c}{ Barat (West) } & \multicolumn{3}{c}{ Timur (East) } \\
\cline { 2 - 7 } & $\begin{array}{c}\text { Jumlah bunga } \\
\text { (Flower number) }\end{array}$ & $\begin{array}{c}\text { Jumlah buah } \\
\text { (Fruit number) }\end{array}$ & Fruit set & $\begin{array}{c}\text { Jumlah bunga } \\
\text { (Flower number) }\end{array}$ & $\begin{array}{c}\text { Jumlah buah } \\
\text { (Fruit number) }\end{array}$ & Fruit set \\
\hline 1 & $13,33 \pm 3,68$ & $2,00 \pm 0,00$ & $0,14 \pm 0,06$ & $12,00 \pm 2,16$ & $1,67 \pm 0,47$ & $0,17 \pm 0,04$ \\
2 & $13,67 \pm 9,07$ & $0,67 \pm 0,58$ & $0,10 \pm 0,13$ & $22,33 \pm 4,51$ & $0,67 \pm 0,58$ & $0,03 \pm 0,03$ \\
3 & $18,67 \pm 4,73$ & $1,00 \pm 1,00$ & $0,05 \pm 0,06$ & $17,00 \pm 7,55$ & $0,67 \pm 0,58$ & $0,03 \pm 0,03$ \\
4 & $17,00 \pm 3,61$ & $1,67 \pm 0,58$ & $0,10 \pm 0,03$ & $20,33 \pm 4,04$ & $1,33 \pm 0,58$ & $0,06 \pm 0,02$ \\
5 & $16,00 \pm 4,58$ & $2,67 \pm 1,15$ & $0,16 \pm 0,03$ & $16,67 \pm 4,16$ & $1,00 \pm 0,00$ & $0,06 \pm 0,02$ \\
6 & $17,67 \pm 6,81$ & $2,67 \pm 0,58$ & $0,18 \pm 0,11$ & $15,67 \pm 5,69$ & $1,33 \pm 0,58$ & $0,10 \pm 0,07$ \\
7 & $14,67 \pm 4,04$ & $2,67 \pm 1,15$ & $0,18 \pm 0,03$ & $14,33 \pm 2,31$ & $2,67 \pm 0,58$ & $0,19 \pm 0,04$ \\
8 & $19,67 \pm 2,52$ & $2,67 \pm 0,58$ & $0,13 \pm 0,02$ & $19,00 \pm 3,61$ & $2,00 \pm 1,00$ & $0,11 \pm 0,05$ \\
9 & $14,00 \pm 3,61$ & $1,67 \pm 0,58$ & $0,12 \pm 0,02$ & $13,67 \pm 5,13$ & $2,33 \pm 0,58$ & $0,19 \pm 0,07$ \\
10 & $17,00 \pm 7,81$ & $1,67 \pm 0,58$ & $0,13 \pm 0,11$ & $19,00 \pm 2,00$ & $1,67 \pm 0,58$ & $0,09 \pm 0,02$ \\
\hline Rataanyyyyyyyy & $16,34 \pm 5,02$ & $1,90 \pm 0,98$ & $0,13 \pm 0,04$ & $17,14 \pm 4,85$ & $1,52 \pm 0,78$ & $0,10 \pm 0,06$ \\
\hline
\end{tabular}

Tabel(Table) 3. Uji-t berpasangan pengaruh dua arah mata angin terhadap variabel reproduksi jenis kemenyan (Paired t-test of the influence of two-sun directions on reproductive variables ofkemenyan)

\begin{tabular}{lcc}
\hline $\begin{array}{c}\text { Variabel } \\
\text { (Variables) }\end{array}$ & $\begin{array}{c}\text { Barat } \\
(\text { West })\end{array}$ & $\begin{array}{c}\text { Timur } \\
(\text { East })\end{array}$ \\
\hline Jumlah bunga (Flower number) & $16,34 \mathrm{a}$ & $17,14 \mathrm{a}$ \\
Jumlah buah (Fruit number) & $1,90 \mathrm{a}$ & $1,52 \mathrm{a}$ \\
Ratio buah/bunga (Fruit set $)$ & $0,13 \mathrm{a}$ & $0,10 \mathrm{a}$ \\
\hline
\end{tabular}

Keterangan (Remarks): Nilai rata-rata yang diikuti huruf sama pada lajur menyatakan tidak berbeda nyata pada $\alpha: 0,05$ (Mean values followed by the same alphabetare not significantly different at $\alpha: 0,05$ ) 
Tabel (Table) 4. Ukuran dimensi pohon dan buah kemenyan pada dahan bagian barat dan timur (Tree and fruit dimension of kemenyan in the West and East)

\begin{tabular}{|c|c|c|c|c|c|c|c|}
\hline \multirow[b]{3}{*}{ No } & \multirow{2}{*}{\multicolumn{3}{|c|}{$\begin{array}{l}\text { Dimensi pohon } \\
\text { (Tree dimension) }\end{array}$}} & \multicolumn{4}{|c|}{$\begin{array}{l}\text { Dimensi buah } \\
\text { (Fruit dimension) }\end{array}$} \\
\hline & & & & \multicolumn{2}{|c|}{$\begin{array}{l}\text { Barat } \\
\text { (West) }\end{array}$} & \multicolumn{2}{|c|}{$\begin{array}{l}\text { Timur } \\
\text { (East) }\end{array}$} \\
\hline & $\begin{array}{l}\text { Diameter } \\
\text { batang } \\
\text { (Stem } \\
\text { diameter } \\
(\mathrm{cm})\end{array}$ & $\begin{array}{c}\text { Tinggi } \\
\text { bebas } \\
\text { cabang } \\
\text { (Branch-free } \\
\text { height }(\mathrm{m})\end{array}$ & $\begin{array}{l}\text { Tinggi } \\
\text { total } \\
\text { (height) } \\
\text { (m) }\end{array}$ & $\begin{array}{l}\text { Diameter } \\
\text { (diameter) } \\
(\mathrm{cm})\end{array}$ & $\begin{array}{l}\text { Panjang } \\
\text { (length) } \\
(\mathrm{cm})\end{array}$ & $\begin{array}{l}\text { Diameter } \\
\text { (diameter) } \\
(\mathrm{cm})\end{array}$ & $\begin{array}{l}\text { Panjang } \\
\text { (length) } \\
(\mathrm{cm})\end{array}$ \\
\hline 1 & 16,9 & 3 & 9 & $2,78 \pm 0,13$ & $2,00 \pm 0,15$ & $2,90 \pm 0,32$ & $2,00 \pm 0,24$ \\
\hline 2 & 17,2 & 3 & 8 & $2,85 \pm 0,35$ & $2,40 \pm 0,57$ & $2,70 \pm 0,14$ & $2,05 \pm 0,21$ \\
\hline 3 & 17,2 & 4 & 11 & $2,67 \pm 0,06$ & $2,07 \pm 0,06$ & $2,85 \pm 0,11$ & $2,00 \pm 0,07$ \\
\hline 4 & 18,5 & 3,5 & 10 & $2,80 \pm 0,40$ & $2,06 \pm 0,15$ & $2,32 \pm 0,23$ & $1,85 \pm 0,17$ \\
\hline 5 & 18,5 & 8 & 12 & $2,74 \pm 0,17$ & $2,08 \pm 0,08$ & $3,07 \pm 0,12$ & $2,40 \pm 0,17$ \\
\hline 6 & 21,6 & 5 & 12 & $2,80 \pm 0,40$ & $2,06 \pm 0,15$ & $3,00 \pm 0,29$ & $2,22 \pm 0,21$ \\
\hline 7 & 23,2 & 6 & 13 & $2,51 \pm 0,19$ & $2,01 \pm 0,11$ & $2,60 \pm 0,29$ & $2,09 \pm 0,12$ \\
\hline 8 & 20,4 & 3 & 13 & $2,95 \pm 0,18$ & $2,21 \pm 0,14$ & $3,07 \pm 0,15$ & $2,18 \pm 0,13$ \\
\hline 9 & 21,6 & 5 & 12 & $2,87 \pm 0,98$ & $2,10 \pm 0,20$ & $3,00 \pm 0,22$ & $2,19 \pm 0,17$ \\
\hline 10 & 20,7 & 5 & 12 & $2,66 \pm 0,05$ & $2,02 \pm 0,08$ & $2,56 \pm 0,11$ & $1,90 \pm 0,07$ \\
\hline $\begin{array}{l}\text { Rataan } \\
\text { (Averages) }\end{array}$ & 61,5 & 4,55 & 11,2 & $2,76 \pm 0,13$ & $2,10 \pm 0,12$ & $2,81 \pm 0,25$ & $2,09 \pm 0,16$ \\
\hline
\end{tabular}

Tabel(Table) 5. Uji-t berpasangan pengaruh dua arah mata angin terhadap variabel dimensi buah kemenyan (Paired t-test of the influence of two-sun directions on fruit dimension of kemenyan)

\begin{tabular}{ccc}
\hline $\begin{array}{c}\text { Variabel } \\
\text { (Variables) }\end{array}$ & $\begin{array}{l}\text { Barat } \\
(\text { West })\end{array}$ & $\begin{array}{l}\text { Timur } \\
(\text { East })\end{array}$ \\
\hline Panjang buah & $2,763 \mathrm{a}$ & $2,807 \mathrm{a}$ \\
Diameter buah & $2,101 \mathrm{a}$ & $2,088 \mathrm{a}$
\end{tabular}

Keterangan(Remarks): Nilai rata-rata yang diikuti huruf sama pada lajur menyatakan tidak berbeda nyata pada $\alpha: 0,05$ (Mean values followed by the same alphabeare not significantly different at $\alpha: 0.05$ ) 


\section{B. Pembahasan}

Siklus reproduksi tanaman kemenyan yang diamati di Arboretum Aek Nauli berlangsung selama 8-9 bulan. Periode ini umum terjadi pada jenis tanaman yang tumbuh di daerah tropis yang memerlukan waktu relatif pendek (kurang dari satu tahun) dibandingkan dengan jenis-jenis yang tumbuh di daerah temperate (Tenorio \& Manriquez, 2007). Namun demikian, awal terjadinya siklus reproduksi pada tumbuhan di daerah tropis kurang konsisten dibandingkan dengan tumbuhan temperate (Owens-Smith \& Ogutu, 2013). Hal ini dapat dimengerti terkait iklim yang terjadi di daerah tropis yang memiliki perbedaan musim yang sedikit (kemarau dan hujan), sehingga proses pembungaan hingga pembuahan tidak terganggu atau terhenti karena pengaruh perubahan iklim empat musim.

Kondisi iklim di Aek Nauli selama periode pengamatan pembungaan dan pembuahan kemenyan memperlihatkan suhu dengan variasi yang rendah $\left(21,0-22,0^{\circ} \mathrm{C}\right)$ pada saat awal pembentukan bunga (Juni-Juli 2012) hingga pembentukan buah matang (Februari-Maret 2013). Demikian juga kelembaban udara (76-85\%) dan curah hujan (125,7-337,4 mm/bulan) yang terjadi pada bulan Juni-Juli 2012 hingga FebruariMaret 2013 relatif kurang berfluktuasi (BMKG, 2013).

Untuk jenis-jenis yang tumbuh pada rentang zona iklim yang luas, peningkatan iklim musiman menyebabkan meningkatnya pembungaan. Seperti misalnya mindi di Thailand yang berbunga dan berbuah sepanjang tahun, sementara mindi di Afrika Timur (Schmidt, 2000) dan di Indonesia (Syamsuwida, 2012) pembungaan dan pembuahan terbatas pada periode waktu tertentu karena memiliki musim basah dan kering yang jelas. Periodesitas reproduksi dapat berubah jika jenis tersebut berada diluar sebaran alaminya.

Menurut Janzen (1978) dalam Owens (1995) sedikitnya ada empat kelompok periodesitas pembungaan pada tanaman tropis dan tanaman kemenyan termasuk ke dalam kategori seasonal flowering (pembungaan musiman) dimana pembungaan terjadi sebagai respon terhadap musim kemarau. Bakal bunga kemenyan di Aek Nauli muncul pada bulan Juni-Juli yaitu saat musim kemarau dimulai dengan curah hujan rata-rata antara $81,5-125,7 \mathrm{~mm} / \mathrm{bulan}$. Fenomena ini umum terjadi pada jenis hutan hujan tropis termasuk Dipterokarpa (Kishimoto-Yamada, 2008;
Ashton, 2008), mangrove (Kamal, 2003), pilang (Syamsuwida et al., 2011), dan mindi (Syamsuwida, 2012).

Kemenyan memiliki organ seksual hermaprodit yaitu dalam satu bunga terdapat organ jantan (stamen) dan organ betina (putik). Fenomena umum dari tanaman hermaprodit adalah menghasilkan ratio buah/bunga yang rendah (Liao et al., 2009, Holland et al., 2004). Ratio buah/bunga kemenyan di Aek Nauli berkisar antara 10-13\%. Nilai fruit set ini cukup rendah seperti halnya terjadi pada Argania spinosa (7-9\%) (Nerd et al., 1998), Enterolobium cyclocarpum (9\%) (Rocha \& Aguilar, 2001), Bombix ceiba (7-10 \%) (Mansoor et al., 2009). Tanaman hutan yang memiliki fruit set yang relatif tinggi, diantaranya Acacia leucophloea dan Albizzia procera, masing-masing $40 \%$ (Syamsuwida et al., 2011).

Pada kenyataannya pembentukan buah (fruit set) dipengaruhi oleh banyak faktor yang berhubungan dengan biologi reproduksi termasuk sistem penyerbukan dan perilaku pembungaannya. Menurut Garibaldi et al. (2013) penyerbukan merupakan faktor pembatas utama dalam produksi buah. Pembungaan yang melimpah akan menarik hewan penyerbuk untuk mengunjungi bunga, selain itu ketersediaan sumberdaya polen juga merupakan faktor yang penting dalam produksi buah (Cuevas et al., 2014). Akan tetapi menurut Liao et al. (2009) pohon dengan pembungaan yang berlimpah mungkin akan menerima kunjungan polinator pada tingkat gen, akan tetapi mungkin hanya sedikit jumlah kunjungan per bunga dan kurangnya polen yang menempel pada permukaan stigma karena banyaknya jumlah bunga yang kurang menerima polen. Selain itu juga individu bunga pada pohon besar kemungkinan dikelilingi oleh pembungaan dengan genetik yang sama, akibatnya proporsi penyerbukan dengan polen berasal dari bunga lain dari tanaman yang sama akan lebih besar, sehingga akan lebih meningkatkan risiko dihasilkannya zigot hasil penyerbukan sendiri (selfed zygotics) dan menurunkan kecocokan tetua melalui depresi inbreeding.

Pembentukan buah pada tanaman kemenyan yang rendah kemungkinan terjadi karena faktor kelimpahan bunga yang kurang sehingga proses penyerbukan tidak optimal. Karena itu penyerbukan akan optimal jika terjadi pada musim puncak pembungaan. Selain itu ketersediaan sumber polennya pun terbatas karena skala densitas tanaman berbunga yang rendah sehingga efisiensi pe- 
nyerbukan berkurang (Heghland, 2014). Walaupun demikian, ketika terjadi penyerbukan yang efisien dan berhasil menjadi buah, namun yang menjadi buah sedikit, maka produksi bunga yang melimpah akan terseleksi dengan mengugurkan buah yang kualitasnya rendah (Torres et al., 2002). Berjano et al. (2006) dalam penelitiannya terhadap jenis Aristolochia paucinervis memperkuat dugaan bahwa rendahnya produksi buah disebabkan oleh tidak optimalnya penyerbukan dan terbatasnya sumberdaya polen, namun konsekuensi relatif tampaknya beragam baik secara spasial maupun temporal.

Melihat struktur organ reproduksi pada kemenyan dimana anther dan stigma sangat berdekatan, maka kemungkinan terjadi penyerbukan sendiri (selfing) sangat besar yang menyebabkan penyerbukan sedikit dan berakibat terhadap rendahnya jumlah buah yang dihasilkan. Waites \& Agren (2006) menyatakan bahwa beberapa tipe posisi stigma dan anther sangat mempengaruhi keberhasilan reproduksi tanaman. Tipe medium dengan stigma di luar corola (kelopak bunga) menghasilkan pembentukan biji yang tinggi melalui proses penyerbukan sendiri (selfing) dan ini menunjukkan jenis yang self compatible. Namun untuk kemenyan masih perlu dibuktikan lebih lanjut dengan melakukan penyerbukan buatan baik penyerbukan sendiri (selfing) maupun penyerbukan silang (outcrossing). Tanaman biasanya menghasilkan banyak ovul dan sedikit yang menjadi biji untuk mengantisipasi kehilangan embrio yang berkembang (Porcher \& Lande, 2005).

Ratio bunga menjadi buah pada kemenyan serta ukuran dimensi buah tidak membedakan perilaku pembungaan dan pembuahan pada dua arah matahari yang berbeda yaitu Barat dan Timur. Cahaya matahari dipancarkan ke segala arah dan hanya sebagian kecil yang diterima bumi. Secara geografis, arah barat dan timur menerima intensitas cahaya yang relatif sama. Perbedaan terjadi ketika ada awan atau hujan yang menghalangi penyinaran matahari (Jumin, 2008). Hal lain yang mungkin terjadi adalah jarak tanam kemenyan di Aek Nauli yang relatif berdekatan $(2 \times 3 \mathrm{~m})$, dan penutupan tajuk yang cukup rapat sehingga diduga cahaya yang masuk relatif sama. Dengan demikian, pertumbuhan dan perkembangan bunga dan buah kemenyan pada arah Barat dan Timur dalam satu pohon menerima penyinaran matahari yang tidak berbeda, sehingga menghasilkan ratio jumlah buah/bunga yang sama $(\mathrm{P}>0,05)$ dan ukuran buah yang sama juga $(\mathrm{P}>0,05)$.

\section{KESIMPULAN DAN SARAN}

\section{A. Kesimpulan}

1. Siklus reproduksi tanaman kemenyan di Arboretum Aek Nauli pada periode tahun 20122013 berlangsung selama 8-9 bulan diawali dari terbentuknya tunas generatif pada bulan Juni-Juli, bunga mekar Agustus dan buah masak pada bulan Februari-Maret.

2. Perilaku pembungaan pada dahan bagian Barat dan Timur tidak menunjukkan perbedaan nyata dengan menghasilkan ratio buah/bunga (fruit set) yang rata-rata rendah yaitu $13 \%$ di Barat dan 10\% di Timur $(\mathrm{P}>0,05)$ serta ukuran dimensi buah yang sama $(\mathrm{P}>0,05)$.

\section{B. Saran}

Dari hasil penelitian ini disarankan untuk meningkatkan nilai fruit set dengan perlakuan teknik silvikultur serta mempelajari manajemen penyerbukan dalam suatu sumber benih kemenyan.

\section{DAFTAR PUSTAKA}

Ashton, P.S. (2008). Speciation among tropical forest trees: Some deductions in the light of recent evidence. Biological Journal of the Linnean Society 1(1-2):155 - 196.

Bawa, K.S, Ashton, P.S., \& Noor, S.M. (1990). Reproductive ecology of tropical forest plants: management issue. In: Reproductive Ecology of Tropical Forest Plants, eds Bawa, K.S. \& Hadley, M. UNESCO Paris and The Parthenon Publishing Group, France, pp. 3 - 11.

Badan Meteorologi Klimatologi dan Geofisika. (2013). Balai Besar Wilayah III. Stasiun Klimatologi Medan. Sumatera Utara.

Berjano, R., Vega, C., Arista, M., Ortiz, P.L., \& Talavera, S. (2006). A Multi-Year Study of Factors Affecting Fruit Production in Aristolochia Paucinervis (Aristolochiaceae), American Journal of Botany 93(4): 599-606.

Cleland, E.E., Allen J.M, Crimmins, T.M, Dunne, J.A., Pau, S., Travers, S.E., et al. (2012). Phenological tracking enables positive species responsesto climate change. Ecology 93(8):17651771.

Cuevas, E., Jiménez, R., \& Lopezaraiza-Mikel, M. (2014). Sex-specific reproductive components 
and pollination ecology in the subdioecious shrub Fuchsia microphylla. Plant Biology 03.

Faruk, M. 2010. Pemilihan uji dalam penelitian (studi tentang uji t-berpasangan). Akses tanggal 6 Januari 2014, dari D./Document/My Document/STATISTIK/STUDI TENTANG UJI-t BERPASANGAN.htm.

Garibaldi, L.A., Dewenter, I.S, Winfree, R., Aizen, M.A, Bommarco, R., Cunningham, et al. (2013). Wild pollinators enhance fruit set of crops regardless of honey bee abundance. Science Vol. 339. Akses tanggal 14 April 2014, dari www.sciencemag.org.

Hegland, S.J. (2014). Floral neighbourhood effects on pollination success in red clover are scaledependent. Function Ecology 11. British Ecological Society.

Holland, J.N., Bronstein, J.L., \& Deangelis, D.L. (2004). Testing hypotheses for excess flower production and low fruit-to-flower ratios in a pollinating seed-consuming mutualism. Oikos 105: 633-640.

Jumin, H.B. (2008). Dasar-Dasar Agronomi. Jakarta: PT Rajagrafindo Persada.

Kamal, E. (2003). Fenologi Mangrove : Rhizophora Apiculata, R. Mucronata, dan R. Stylosa di Pulau Unggas Air Bangis, Pasaman, Sumatera Barat, Indonesia. Mangrove dan Pesisir Vol. III No. 3 .

Kishimoto-Yamada, K., Itioka, T. (2008). Survival of flower-visiting chrysomelids during non general-flowering periods in Bornean Dipterocarp Forests. Biotropica 40 (5):600 - 606.

Liao, W.J, Hu, Y., Rzhu, B., Qzhao, X., Fzeng, Y., Yzhang, D. (2009). Female reproductive success decreases with display size in monkshood Aconitum kusnezoffii (Ranunculaceae). Annals of Botany 104: 1405-1412.

Lovelless, D. Marylin, Grogan, \& James. (2006). Flowering phenology, flowering neighborhood, and fruiting in Swietenia macrophylla, Big-Leaf Mahagony, in Southern Para, Brazil. Akses tanggal 26 Juni 2011, dari http://www. 2006.botanyconference.org/engine/search/ind ex.php? func $=$ detail \&aid $=442$.

Mansoor M, Chauhan, S., \& Rana, A. (2009). Phenology and reproductive biology of Bombax ceiba Linn. (Bombacaceae). The International Journal of Plant Reproductive Biology 1(2): 173-178.

Owens, J.N, Sornsathaporhkul, P., \& Tangmitchareon, S. (1991). Studying flowering and seed on- togeny in tropical forest trees. Thailand: Asean-Canada Forest Tree Seed Centre and Royal Forest Depart.

Owens, J.N. (1995). Constraints to seed production: Temperate and tropical forest trees. Tree Physiology 15, 477-484. Canada: Heron Publishing. Victoria.

Owen-Smith, N., \& Ogutu, J.O. (2013). Controls over reproductive phenology among ungulates: allometry and tropical-temperate contrasts. Ecography, 36(3):256-263.

Porcher, E., \& Lande, R. (2005). Reproductive compensation in the evolution of plant mating systems. New Phytologist 166: 673-684.

Rocha, O.J., \& Aguilar, G. (2001). Reproductive biology of the dry forest tree Enterolobium Cyclocarpum (Guanacaste) in Costa Rica: A Comparison between trees left in Pastures and Trees in continuous forest. American Journal of Botany 88 (9): 1607-1614.

Schmidt, L. (2000). Guide to handling of tropical and subtropical forest seed. Denmark: Danida Forest Seed Centre. Humlebaek. p 511.

Syamsuwida, D. (2010). Fenologi dan teknik pemanenan (Pengunduhan) benih tanaman penghasil kayu energi jenis weru (Albizia procera) dan pilang (Acacia leucophloea). Tidak diterbitkan. Laporan Hasil Penelitian. Balai Penelitian Teknologi Perbe-nihan. Bogor.

Syamsuwida, D., Aminah, A., \& Muharam, A. (2011). Fenologi dan potensi produksi benih tanaman penghasil kayu energi jenis weru (Albizia procera), pilang (Acacia leucophloea), akor (Acacia auriculiformis) dan kaliandra (Caliandra callothyrsus). Tidak diterbitkan. Laporan Hasil Penelitian. Balai Penelitian Teknologi Perbenihan. Bogor .

Syamsuwida, D. (2012). Aspek biologi dan genetik pada sistem reproduksi mindi (Melia azedarach Linn.). Tidak diterbitkan. Disertasi Doktor. Sekolah Pascasarjana. Institut Pertanian Bogor.

Tabla, V. P., \& Vargas, C.F. (2004). Phenology and phenotypic natural selection on the flowering time of a deceit-pollinated tropical orchid, Myrmecophila christinae. Annals of Botany, 94(2):243-250. Akses tanggal 26Juni 2006E, dari http://aob.oxfordjournals. org/cgi/content/ full/ $94 / 2 / 243$.

Tenorio, G.C., \& Manriquez, G.I. (2007). Plant reproductive phenology in a temperate forest of the Monarch Butterfly Biosphere Reserve, Mexico. Interciencia Vol.32(7):445-452. 
Torres, C, Eynard, M.C., Aizen, M.A., \& Galetto, L. (2002). Selective fruit maturation and seedling performance in Acacia caven (Fabaceae). In- ternational Journal of Plant Sciences 163: 809813. Akses tanggal 10 April 2013, dari www.forda-mof.org/files/Anu-Aek\%20 Nauli.pdf. 